\title{
KNOWLEDGE AND ATTITUDE ON ANTIBIOTIC USE AMONG PUBLIC IN RURAL AREA BATU PAHAT, JOHOR
}

\author{
Chow $\mathrm{CQ}^{1,2}$ and Nor Liana $\mathrm{CY}^{3^{*}}$ \\ ${ }^{1}$ Department of Pharmacy, Hospital Sultanah Aminah, Jalan Persiaran Abu Bakar Sultan, 80100 Johor Bahru, Johor. \\ ${ }^{2}$ Department of Pharmacy Practice, Faculty of Pharmacy, Mahsa University, JIn SP 2, Bandar Saujana Putra, 42610 Jenjarom, \\ Selangor, Malaysia \\ ${ }^{3}$ Unit of Clinical Pharmacy, School of Pharmacy, Management and Science University, University Drive, Off Persiaran \\ Olahraga, 40100 Shah Alam Selangor, Malaysia
}

Corresponding authors: Nor Liana Che Yaacob

Email: nor_liana@msu.edu.my, Lyanas76@yahoo.com

\begin{abstract}
Antibiotic resistance is a global threat to public health, leads to health and economic burden. Studies show that knowledge and attitude towards antibiotic use is poor, especially among rural residents. However, there is no study conducted on knowledge and attitude towards antibiotic use among the public in rural area Malaysia. The aim of this study is to assess knowledge and attitude on antibiotic use among public in rural area Batu Pahat, Johor. This was a cross-sectional study in which closed-ended questionnaires were distributed to 350 rural residents in Batu Pahat by convenience sampling method. The questionnaire was constructed into socio-demographic, antibiotic use and indication, knowledge and attitude towards antibiotic use. The most inappropriate knowledge responses were found for assumption about the effectiveness of antibiotics towards viral infection (69.1\%), colds and coughs (57.7\%). Only few were aware about the decrease in antibiotic effectiveness following antibiotic overuse (29.1\%). Misuse antibiotics for cold (64.0\%), expect antibiotics to be prescribed for common cold symptoms (52.6\%) and discontinue antibiotics when start feeling better (63.4\%) were the several highest inappropriate responses in attitude domain. Significant association was shown between both knowledge level and attitude level with age, gender, educational level, monthly income, occupation related to healthcare, family member's occupation related to healthcare and most common location seek for healthcare. In conclusion, the rural residents demonstrated moderate knowledge (50\%) but negative attitude (56.9\%) towards antibiotic use. To cope with antibiotic resistance issue, proper planning on effective methods to promote appropriate use of antibiotics are necessary.
\end{abstract}

Keywords: Knowledge, attitude, antibiotic, antibiotic use, public.

\section{INTRODUCTION}

Antibiotic resistance is a global threat to human health. It leads to longer hospitalization, higher medical costs and mortality. All levels of society play a significant role in minimizing the spread of antibiotic resistance ${ }^{1}$. Currently, knowledge on safe use of antibiotics have been widely disseminated via media, internet, community, schools, etc. This includes implementation of antibiotic awareness week in November every year using info graphics, quiz, posters, and successful stories to raise awareness on antibiotic resistance.

Antibiotic knowledge influences proper usage of antibiotic. Despite the efforts to raise antibiotic awareness, the prevalence of inappropriate antibiotic use remains high. Furthermore, previous study showed that there was significant disparity in antibiotic knowledge by educational status, occupation, race and residency. Non-compliance with antibiotics therapy has led to the development of antibiotic resistance ${ }^{2}, 3$. This was further exacerbated by the majority of patients who are seeking antibiotics as treatment, resulting in widespread and abuse of antibiotic.

In order to aid policy makers to initiate strategies to overcome AMR, there is a need to assess public knowledge and attitude towards antibiotic use, especially among under served population, such as rural residents. In Malaysia, several studies were conducted on similar topics among public in Penang, Shah Alam, Putrajaya, Kedah and Kuala Lumpur, but these studies did not differentiate the residency (rural or urban) of respondents. Therefore, the purpose of this study is to resolve research gaps existed from previous study in Malaysia by expanding the study site to rural area in Malaysia. 
Aim of the study was to investigate knowledge and attitude towards antibiotic use among the general public in rural area Batu Pahat, Johor.

\section{METHODOLOGY}

This was a cross-sectional study conducted among 350 rural residents in two villages of Batu Pahat, Johor, namely Kampung Sungai Jambi, Rengit $\left(1.672^{\circ} \mathrm{N}, 103.18^{\circ} \mathrm{E}\right)$ and Kampung Parit Haji Ali, Parit Raja $\left(2.0061^{\circ} \mathrm{N}, 102.6421^{\circ} \mathrm{E}\right)$. The villages were selected based on the village entry data in Ministry of Rural and Regional Development Malaysia ${ }^{4}$. The study was conducted in cafe, shop house, bus station, community halls and outside the mosque. The study excluded those never heard of the term "antibiotic". The questionnaire was adopted from study conducted by Lim K.K. to assess public knowledge and attitude towards antibiotics in Putrajaya, Malaysia ${ }^{5}$. It consisted of a total of 31 items and was divided into four parts. Part I consisted 8 items on socio-demographic information of the respondents. Part II comprised of 3 items on antibiotic use and indication in the past 4 weeks. Part III contained 12 items regarding knowledge on antibiotic use. Participants were required to answer "yes", "no" or "not sure" for each statements. Part IV had 8 items concerned about attitude towards antibiotics use. Participants were required to use a 5-point Likert scale to answer these statements, which were "strongly agree", "agree", "not sure", "disagree" and "strongly disagree". To simplify the analysis, options of "strongly agree" and "agree" were classified as "agree", whereas options of "strongly disagree" and "disagree" were classified as "disagree" and option of "not sure" was remained as "not sure". Score 1 was awarded to appropriate responses and vice versa. By adding up the score, level of knowledge was categorised into three levels based on the score, which were poor (0-3), moderate (4-7) and good (8-12). Respondents were categorised into negative attitude (0-4) and positive attitude (5-8).

\section{RESULT}

Part I: Socio-demographic data of respondents Table 1 shows the socio-demographic data of respondents. Respondents spread out almost equally among all age groups. Majority of respondents were male $(63.4 \%)$, secondary school level $(66.6 \%)$ and not involved in healthcare services $(88.9 \%)$. All of the respondents were Malay $(100 \%)$.

Table 2 demonstrates the antibiotic use and indications of participants. Most of the respondents used antibiotic in the past 4 weeks (51.1\%). 84.0\% of respondents received antibiotics that were prescribed and given by hospital or clinic after consultation. Majority used antibiotics for fever (56.4\%).

Table 3 shows the knowledge of respondents of antibiotic use. $47.1 \%$ of respondents disagreed that antibiotics are the same as medications used to relieve pain and fever such as aspirin and paracetamol (Panadol). Majority of respondents also agreed that antibiotics can be used to treat viral infections $(69.1 \%)$. Besides that, $57.7 \%$ of respondents assumed that antibiotics work on most colds and coughs. However, $61.1 \%$ of respondents were uncertain that overuse of antibiotics can cause the antibiotics to lose effectiveness in long term. For the statements regarding administration of antibiotics, $58.6 \%$ of respondents disagreed that it is okay to stop taking an antibiotic when symptoms are improving.

Table 4 shows the attitude of respondents towards antibiotic use. Majority of the respondents agreed that they will take antibiotics to help them get better more quickly when they get cold (64.0\%). Besides that, $52.6 \%$ of respondents were expecting antibiotic to be prescribed by doctor if they suffer from common cold symptoms. On top of these, most of the respondents normally stop taking on antibiotic when they start feeling better (63.4\%). 
Table 1: Socio-demographic data of respondents $(n=350)$

\begin{tabular}{|c|c|c|}
\hline Variables & Frequency, $\mathrm{n}$ & Percentage, $\%$ \\
\hline \multicolumn{3}{|l|}{ Age } \\
\hline $18-30$ years old & 87 & 24.9 \\
\hline $31-40$ years old & 59 & 16.9 \\
\hline $41-50$ years old & 87 & 24.9 \\
\hline $51-60$ years old & 78 & 22.3 \\
\hline More than 60 years old & 39 & 11.1 \\
\hline \multicolumn{3}{|l|}{ Gender } \\
\hline Male & 223 & 63.4 \\
\hline Female & 128 & 36.6 \\
\hline \multicolumn{3}{|l|}{ Race } \\
\hline Malay & 350 & 100.0 \\
\hline Chinese & 0 & 0.0 \\
\hline Indian & 0 & 0.0 \\
\hline Others & 0 & 0.0 \\
\hline \multicolumn{3}{|l|}{ Highest education level } \\
\hline Primary school or lower & 28 & 8.0 \\
\hline Secondary school & 233 & 66.6 \\
\hline College/ University & 89 & 25.4 \\
\hline \multicolumn{3}{|l|}{ Monthly income } \\
\hline Less than RM 1000 & 76 & 21.7 \\
\hline RM 1000- RM 2000 & 163 & 46.6 \\
\hline RM 2001- RM 4000 & 83 & 23.7 \\
\hline More than RM 4000 & 28 & 8.0 \\
\hline \multicolumn{3}{|l|}{ Occupation related to healthcare } \\
\hline Yes & 39 & 11.1 \\
\hline No & 311 & 88.9 \\
\hline \multicolumn{3}{|c|}{ Family member's occupation related to healthcare } \\
\hline Yes & 54 & 15.4 \\
\hline No & 296 & 84.6 \\
\hline \multicolumn{3}{|c|}{ Most common location seek for healthcare } \\
\hline Government clinic/ hospital & 297 & 84.9 \\
\hline Private clinic/ hospital & 36 & 10.3 \\
\hline Community pharmacy & 17 & 4.9 \\
\hline Others & 0 & 0.0 \\
\hline
\end{tabular}

Table 2: Antibiotic use and indications

\begin{tabular}{lcc}
\hline Items & Number, $\mathbf{n}$ & Percentage, $\%$ \\
\hline Recent use of antibiotic & 179 & 51.1 \\
$\quad$ Yes & 171 & 48.9 \\
$\quad$ No & 152 & 84.0 \\
Source of antibiotic & & \\
$\quad$ Prescribed and given by hospital/ clinic & & 13.3 \\
after consultation & 24 & \\
Purchased from a private clinic without & & 2.8 \\
$\quad$ Consultation with a doctor & 5 & 0.0 \\
Purchased from a retail pharmacy & 0 & 2.8 \\
$\quad$ Use someone else's antibiotic & & 38.1 \\
Reasons of taking antibiotic & 5 & 56.4 \\
$\quad$ Urinary tract infection & 69 & 0.0 \\
$\quad$ Skin problem/wound & 102 & 2.8 \\
Fever & 0 & 5 \\
$\quad$ Pain/ inflammation & 5 & \\
Respiratory tract infection & & \\
\hline
\end{tabular}


Table 3: Knowledge of respondents on antibiotic use

\begin{tabular}{|c|c|c|c|}
\hline Statements & $\begin{array}{l}\text { Yes } \\
\mathrm{n}(\%)\end{array}$ & $\begin{array}{c}\text { No } \\
\mathrm{n}(\%)\end{array}$ & $\begin{array}{c}\text { Not sure } \\
\mathrm{n}(\%)\end{array}$ \\
\hline \multicolumn{4}{|l|}{ Identification of antibiotics } \\
\hline $\begin{array}{l}\text { 1. Antibiotics are the same as medications used to } \\
\text { relieve pain } \\
\text { and fever such as aspirin and paracetamol } \\
\text { (Panadol). }\end{array}$ & $119(34.0)$ & $165(47.1)$ & $66(18.9)$ \\
\hline 2. Penicillin is an antibiotic. & $98(28.0)$ & $71(20.3)$ & $181(51.7)$ \\
\hline \multirow{2}{*}{$\begin{array}{l}\text { Role of antibiotic } \\
\text { 3. Antibiotics are medicines that can kill bacteria. }\end{array}$} & $345(98.6)$ & $5(1.4)$ & $0(0.0)$ \\
\hline & $242(69.1)$ & $62(17.7)$ & $46(13.1)$ \\
\hline \multicolumn{4}{|l|}{ 4. Antibiotics can be used to treat viral infections. } \\
\hline \multicolumn{4}{|l|}{ 5. Antibiotics work on most colds \& coughs. } \\
\hline \multicolumn{4}{|l|}{ Good bacteria } \\
\hline \multirow{2}{*}{$\begin{array}{l}\text { 6. Antibiotics can kill bacteria that normally live on } \\
\text { the skin and gut (digestion tract). }\end{array}$} & $132(37.7)$ & $26(7.4)$ & $192(54.9)$ \\
\hline & $61(17.4)$ & $44(12.6)$ & $245(70.0)$ \\
\hline \multicolumn{4}{|l|}{$\begin{array}{l}\text { 7. Bacteria that normally live on the skin and in the } \\
\text { gut are good for your health. }\end{array}$} \\
\hline \multicolumn{4}{|l|}{ Adverse effects } \\
\hline 8. Antibiotics may cause allergy reactions. & $193(55.1)$ & $23(6.6)$ & $134(38.3)$ \\
\hline 9. Antibiotics do not cause side effects. & $144(41.1)$ & $63(18.0)$ & $143(40.9)$ \\
\hline $\begin{array}{l}\text { 10. Overuse of antibiotics can cause the antibiotics } \\
\text { to lose effectiveness in long term. }\end{array}$ & $102(29.1)$ & $34(9.7)$ & $214(61.1)$ \\
\hline \multicolumn{4}{|l|}{ Administration of antibiotic } \\
\hline $\begin{array}{l}\text { 11. It is okay to stop taking an antibiotic when } \\
\text { symptoms are improving. }\end{array}$ & $109(31.1)$ & $205(58.6)$ & $36(10.3)$ \\
\hline $\begin{array}{l}\text { 12. Taking less antibiotic than prescribed is } \\
\text { healthier than taking the full course prescribed. }\end{array}$ & $72(20.6)$ & $241(68.9)$ & $37(10.6)$ \\
\hline
\end{tabular}

Based on Figure 1, half of the respondents possessed moderate level of knowledge on antibiotic use (50\%), followed by $36 \%$ of respondents had poor level of knowledge and $14 \%$ of respondents possessed good level of knowledge on antibiotic use. Majority of respondents possessed negative attitude towards antibiotic use $(56.9 \%)$ whereas $43.1 \%$ of respondents exhibited positive attitude towards antibiotic use. 
Table 4: Attitude of respondents towards antibiotic use

\begin{tabular}{|c|c|c|c|c|}
\hline No. & Statements & $\begin{array}{l}\text { Agree } \\
\text { n (\%) }\end{array}$ & $\begin{array}{l}\text { Disagree } \\
\text { n (\%) }\end{array}$ & $\begin{array}{l}\text { Not sure } \\
\mathrm{n}(\%)\end{array}$ \\
\hline 1. & $\begin{array}{l}\text { When I get cold, I will take antibiotics to help } \\
\text { me get better more quickly. }\end{array}$ & $224(64.0)$ & $108(30.9)$ & $18(5.1)$ \\
\hline 2. & $\begin{array}{l}\text { I expect antibiotic to be prescribed by my } \\
\text { doctor if I suffer from common cold } \\
\text { symptoms. }\end{array}$ & $184(52.6)$ & $102(29.1)$ & $64(18.3)$ \\
\hline 3. & $\begin{array}{l}\text { I normally stop taking on antibiotic when I } \\
\text { start feeling better. }\end{array}$ & $222(63.4)$ & $127(36.3)$ & $1(0.3)$ \\
\hline 4. & $\begin{array}{l}\text { If my family member is sick I usually give my } \\
\text { antibiotic to them. }\end{array}$ & $125(35.7)$ & $174(49.7)$ & $51(14.6)$ \\
\hline 5. & $\begin{array}{l}\text { I normally keep antibiotic stock at home in } \\
\text { case of emergency. }\end{array}$ & $125(35.7)$ & $181(51.7)$ & $44(12.6)$ \\
\hline 6. & $\begin{array}{l}\text { I will use leftover antibiotics for a respiratory } \\
\text { illness (runny nose/ sore throat/ flu). }\end{array}$ & 157 (44.9) & $110(31.4)$ & $83(23.7)$ \\
\hline 7. & $\begin{array}{l}\text { I will take antibiotic according to the } \\
\text { instruction on the label. }\end{array}$ & $323(92.3)$ & $23(6.6)$ & $4(1.1)$ \\
\hline 8. & $\begin{array}{l}\text { I normally will look at the expiry date of } \\
\text { antibiotic before taking it. }\end{array}$ & $312(89.1)$ & $0(0.0)$ & 38 (10.9) \\
\hline
\end{tabular}

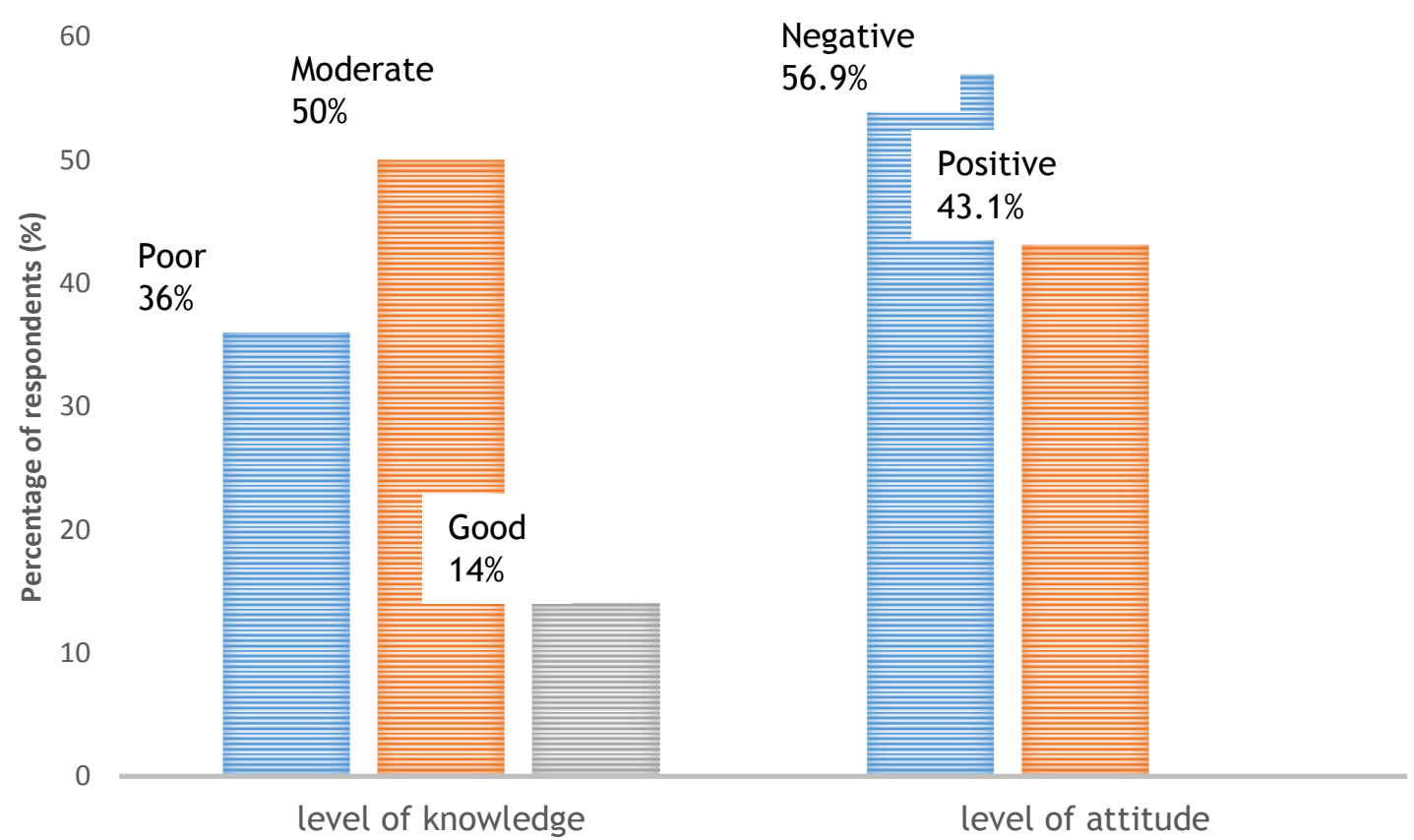

Figure 1: Level of knowledge and level of attitude towards antibiotic use 
Table 5: Association between socio-demographic data and level of knowledge of antibiotic use and level of attitude towards antibiotic use

\begin{tabular}{|c|c|c|c|c|c|c|c|}
\hline \multirow[t]{2}{*}{ Variables } & \multicolumn{3}{|c|}{ Level of knowledge, $n$ (\%) } & \multirow{2}{*}{$\begin{array}{c}\mathrm{p}- \\
\text { value }\end{array}$} & \multicolumn{2}{|c|}{ Level of attitude, $n$ (\%) } & \multirow{2}{*}{$\begin{array}{c}\mathrm{p}- \\
\text { value }\end{array}$} \\
\hline & $\begin{array}{l}\text { Poor } \\
(0-3)\end{array}$ & $\begin{array}{c}\text { Moderate } \\
(4-7)\end{array}$ & $\begin{array}{l}\text { Good } \\
(8-12)\end{array}$ & & $\begin{array}{l}\text { Negative } \\
(0-4)\end{array}$ & $\begin{array}{l}\text { Positive (5- } \\
8)\end{array}$ & \\
\hline \multicolumn{8}{|l|}{ Age } \\
\hline $18-30$ & $12(3.4)$ & $72(20.6)$ & $3(0.9)$ & \multirow{5}{*}{$<0.001$} & $34(9.7)$ & $53(15.1)$ & \multirow{5}{*}{0.003} \\
\hline $31-40$ & $18(5.1)$ & $25(7.1)$ & $16(4.6)$ & & $36(10.3)$ & $23(6.6)$ & \\
\hline $41-50$ & $46(13.1)$ & $33(9.4)$ & $8(2.3)$ & & $58(16.6)$ & $29(8.3)$ & \\
\hline $51-60$ & $27(7.7)$ & $32(9.1)$ & $19(5.4)$ & & $47(13.4)$ & $31(8.9)$ & \\
\hline$>60$ & $23(6.6)$ & $13(3.7)$ & $3(0.9)$ & & $24(6.9)$ & $15(4.3)$ & \\
\hline \multicolumn{8}{|l|}{ Gender } \\
\hline Male & $85(24.3)$ & $114(32.6)$ & $23(6.6)$ & \multirow[t]{2}{*}{0.033} & $152(43.4)$ & $70(20)$ & \multirow[t]{2}{*}{$<0.001$} \\
\hline Female & 41 (11.7) & $61(17.4)$ & $26(7.4)$ & & $47(13.4)$ & $81(23.1)$ & \\
\hline \multicolumn{8}{|l|}{ Race } \\
\hline Malay & $126(36)$ & $175(50)$ & $49(14)$ & \multirow{4}{*}{ 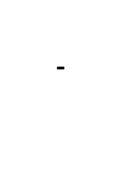 } & $199(56.9)$ & $151(43.1)$ & \multirow{4}{*}{ - } \\
\hline Chinese & $0(0)$ & $0(0)$ & $0(0)$ & & $0(0)$ & $0(0)$ & \\
\hline Indian & $0(0)$ & $0(0)$ & $0(0)$ & & $0(0)$ & $0(0)$ & \\
\hline Others & $0(0)$ & $0(0)$ & $0(0)$ & & $0(0)$ & $0(0)$ & \\
\hline \multicolumn{8}{|l|}{$\begin{array}{l}\text { Highest education } \\
\text { level }\end{array}$} \\
\hline Primary school & $19(5.4)$ & $3(0.9)$ & $6(1.7)$ & \multirow[b]{2}{*}{$<0.001$} & $23(6.6)$ & $5(1.4)$ & \multirow[t]{6}{*}{0.025} \\
\hline $\begin{array}{l}\text { or } \\
\text { lower }\end{array}$ & & & & & & & \\
\hline Secondary & $102(29.1)$ & $112(32)$ & $19(5,4)$ & & $146(417)$ & $87(249)$ & \\
\hline school & $5(1.4)$ & & & & & $08(24.7)$ & \\
\hline College/ & & $60(17.1)$ & $24(6.9)$ & & $30(8.6)$ & & \\
\hline University & & & & & & & \\
\hline \multicolumn{8}{|l|}{ Monthly income } \\
\hline <RM 1000 & $14(4)$ & $56(16)$ & $6(1.7)$ & \multirow{4}{*}{$<0.001$} & $35(10)$ & $41(11.7)$ & \multirow{4}{*}{0.025} \\
\hline RM1000-RM2000 & $76(21.7)$ & $60(17.1)$ & 27 (7.7) & & $106(30.3)$ & $57(16.3)$ & \\
\hline RM2001-RM4000 & $28(8)$ & 41 (11.7) & $14(4)$ & & $42(12)$ & 41 (11.7) & \\
\hline$>\mathrm{RM} 4000$ & $8(2.3)$ & $18(5.1)$ & $2(0.6)$ & & $16(4.6)$ & $12(3.4)$ & \\
\hline \multicolumn{8}{|l|}{$\begin{array}{l}\text { Occupation } \\
\text { related to }\end{array}$} \\
\hline healthcare & & & & \multirow[t]{2}{*}{$<0.001$} & & & \\
\hline Yes & $0(0)$ & $17(4.9)$ & $22(6.3)$ & & $11(3.1)$ & $28(8)$ & $<0.001$ \\
\hline No & $126(36)$ & $158(45.1)$ & 27 (7.7) & & $188(53.7)$ & $123(35.1)$ & \\
\hline \multirow{2}{*}{\multicolumn{8}{|c|}{$\begin{array}{l}\text { Family member's } \\
\text { occupation } \\
\text { related to } \\
\text { healthcare } \\
\text { Yes }\end{array}$}} \\
\hline & & & & & & & \\
\hline No & $7(2)$ & 47 (13.4) & $0(0)$ & \multirow[t]{3}{*}{$<0.001$} & $22(6.3)$ & $32(9.1)$ & 0.009 \\
\hline & $119(34)$ & $128(36.6)$ & $49(14)$ & & $177(50.6)$ & $119(34)$ & \\
\hline $\begin{array}{l}\text { Most common } \\
\text { location seek for } \\
\text { healthcare }\end{array}$ & & & & & & & \\
\hline $\begin{array}{l}\text { Government } \\
\text { clinic/ }\end{array}$ & $126(36)$ & $123(35.1)$ & 48 (13.7) & & 167 (47.7) & $130(37.1)$ & \\
\hline hospital & & & & $<0.001$ & & & \\
\hline $\begin{array}{l}\text { Private clinic/ } \\
\text { hospital }\end{array}$ & $0(0)$ & $35(10)$ & $1(0.3)$ & & $16(4.6)$ & $20(5.7)$ & 0.003 \\
\hline $\begin{array}{l}\text { Community } \\
\text { pharmacy }\end{array}$ & $0(0)$ & 17 (4.9) & $0(0)$ & & $16(4.6)$ & $1(0.3)$ & \\
\hline Others & $0(0)$ & $0(0)$ & $0(0)$ & & $0(0)$ & $0(0)$ & \\
\hline
\end{tabular}


Age group 41-50 age possessed poor knowledge on antibiotic use $(13.1 \%$ versus others $<8 \%)$. Poor level of knowledge was associated with male (24.3\% versus $11.7 \%)$, secondary school level $(29.1 \%$ versus others $<6 \%$ ), monthly income of RM 1000-RM 2000 $(21.7 \%$ versus others $<10 \%)$ and occupation not related to health care.

Age group 18-30 years old were associated with positive attitude $(15.1 \%$ versus others $<10 \%)$. Negative attitude was significantly associated with male $(43.4 \%$ versus $13.4 \%)$, secondary school level $(41.7 \%$ versus others $<10 \%)$, occupation not related to healthcare $(53.7 \%$ versus $3.1 \%)$, monthly income of RM1000-RM2000 (30.3\% versus others $<13 \%$ ).

\section{DISCUSSION}

Respondents used antibiotics in the past month was significantly higher than studies conducted in Putrajaya (16.5\%), Shah Alam (29.2\%) and Penang $(28.9 \%)^{5-7}$. The most common indications for using antibiotics by respondents of this study were fever $(56.4 \%)$ and skin problem or wound (38.1\%). This might be due to rural residents were more likely to involved in agriculture field, which might lead to injury or wound infections ${ }^{8}$. The result was slightly different from previous studies conducted in Malaysia. Oh et al. (2010) reported fever (40.7\%) and respiratory tract infection (22.9\%) were the two highest rated reasons for taking antibiotics ${ }^{6}$.

The majority of the public were less knowledgeable pertaining to the role of antibiotics, where they agreed that antibiotics are useful in treating viral infection (69.1\%). This was similar to other studies conducted in Putrajaya (82\%) and Penang (67.2\%) and rural areas in Jiangxi (79\%) and Heilongjiang province of China $(57.8 \%)^{5}, 6,9,10$. There might be a confusion between the term "bacteria" and "virus". Thus, healthcare providers should use the term "bacteria" and "virus" during consultation or dispensing ${ }^{11}$.

Furthermore, most of the respondents $(57.7 \%)$ assumed antibiotics work on most colds and coughs. This trend was slightly lower than studies conducted in China-10. This might be due to overprescribing of antibiotics for these illnesses, which misguided the belief about antibiotic use among the public ${ }^{12}$.

In the current study, $58.6 \%$ of respondents realised that it was inappropriate to discontinue antibiotic when symptoms are improving. This was considerably higher than the study conducted in China, where only $37.0 \%$ of rural residents disagreed to withdraw antibiotics as soon as the symptoms disappear ${ }^{10}$. This might be due to assumption that antibiotics are equivalent to medications used to relieve pain and fever such as aspirin and paracetamol (Panadol), where this statement was agreed by $34.0 \%$ of respondents. Hence, it was acceptable to discontinue antibiotics in the similar way that they would discontinue painkiller and antipyretic once symptoms improved ${ }^{7}$.

By comparing with the respondents who correctly responded that they should complete the full course of antibiotics (58.6\%), there were only $29.1 \%$ of respondents knew that overuse of antibiotics will affect its efficacy. This demonstrated that the public were not aware of the actual reason and the importance of completing the full antibiotic regimen ${ }^{6}$.

The highest inappropriate response in attitude domain was that the public will take antibiotics to resolve the symptoms when they suffer from colds $(64.0 \%)$, which was comparatively higher than studies conducted in Putrajaya (61.8\%), Shah Alam $(47.6 \%)$ and Penang $(38 \%)^{5-7}$. In fact, misunderstanding on the effectiveness of antibiotics towards viral illnesses might be one of the contributing factors to the expectation of antibiotic to be prescribed for common cold, which was shown by $52.6 \%$ of respondents in this study. This was supported by Ebrahim et al. (2014), where $61.7 \%$ of rural mothers requested doctors to prescribe antibiotics for cough and cold to their children ${ }^{13}$. Several studies showed that physicians were more likely to prescribe antibiotics under pressured clinical context. However, overestimation of patients' expectation might occur, resulting in unnecessary prescribing of antibiotics ${ }^{14-}$ 15. The desire to maintain doctor-patient relationship might be another reason for prescribing antibiotic. Nevertheless, several studies demonstrated that patients believe in doctors' decision despite they do not prescribe antibiotics. This proves that, by providing adequate explanation on patients' illnesses, they would be satisfied whenever antibiotics were not given ${ }^{11}$.

In addition, $63.4 \%$ of respondents normally stop taking antibiotics once they start feeling better, which was comparatively higher than studies conducted in Penang (37.0\%) and Shah Alam $(36.6 \%)^{6-7}$. By looking at the responses to the knowledge on administration of antibiotics, the majority of respondents were aware about the necessity to complete the full course of antibiotics (58.6\%). In comparison, the public did not intend to practice according to their knowledge. This supported the study conducted in Shah Alam ${ }^{7}$, where the number of patients who actually completed all the antibiotics was lesser than the 
number of patients who knew that completion of full course of antibiotics was necessary ${ }^{14}$.

Based on current study, about one third of respondents (35.7\%) had negative attitude towards the statement of storage of antibiotics at home in case of emergency. Similarly, Hassali et al. (2017) reported $39.0 \%$ of young Malaysian adults (18- 35 years old) kept antibiotics for emergency ${ }^{12}$. Parallel to this, $50.7 \%$ of rural mothers in Gharbia governorate were reported to keep antibiotics for future use $\mathrm{e}^{13}$. However, this was significantly higher compared to studies conducted in Putrajaya (17\%), Penang (19.9\%) and Shah Alam (19.2\%)

The study setting involved only two villages, which lead to limited generalisability of the results to whole Malaysia population. Besides that, responses from those who could not read or understand either English or Malay language were not able to assess.

\section{CONCLUSION}

There was an inadequate knowledge on antibiotic use among rural residents, where the knowledge level ranged from poor to moderate. Moreover, majority exhibited negative attitude towards antibiotic use. It is recommended for appropriate authorities to conduct strategic planning to enhance proper antibiotic use by targeting rural areas besides the general public in cities or suburban areas.

\section{ACKNOWLEDGEMENT}

I would like to thank Management and Science University (MSU) and Mahsa University for the approval and fund this collaboration study.

\section{REFERENCE}

1. World Health Organization, 2017a, Use antibiotics wisely to combat rising drug resistance.

http: / / www. who.int/campaigns/worldantibiotic-awareness-week/2017/launchevent/en/ (accessed 23 November 2017).

2. Mazinska, B., Strużycka, I. and Hryniewicz, W. 2017, Surveys of public knowledge and attitudes with regard to antibiotics in Poland: Did the European antibiotic awareness day campaigns change attitudes? PLOS ONE 12: e0172146.

3. Ayukekbong, J.A., Ntemgwa, M. and Atabe, A.N. 2017, The threat of antimicrobial resistance in developing countries: causes and control strategies, Antimicrobial Resistance \& Infection Control 6: 47.

4. Kannan, H.K. 2016, Abuse of antibiotics in Malaysia on the rise, says health ministry. https: / /www.nst.com.my/node/189191 (assessed 21 November 2017).

5. Lim, K.K. and Teh, C.C. 2012, A cross sectional study of public knowledge and attitude towards antibiotics in Putrajaya, Malaysia, Southern Medical Review 5: 26.

6. Oh, A.L., Hassali, M.A., Al-Haddad, M.S., Sulaiman, S.A.S., Shafie, A.A. and Awaisu, A. 2010, Public knowledge and attitudes towards antibiotic usage: Across-sectional study among the general public in the state of Penang, Malaysia, The Journal of Infection in Developing Countries 5: 338-347.

7. Qamar, M., Sheikh Abdullah, N.H., Khan, J., Mahmud, A. and Ahmad, A. 2014, Knowledge and attitude towards antibiotic usage among general public in Shah Alam, Malaysia, UK Journal of Pharmaceutical and Biosciences (UK J Pharm Biosci) 2: 60-66.

8. Gebeyehu, E., Bantie, L. and Azage, M. 2015, Inappropriate use of antibiotics and its associated factors among urban and rural communities of Bahir Dar city administration, Northwest Ethiopia, PLOS one 10: e0138179.

9. Gu, J., Zhao, J., Huang, Y., Yang, W., Ren, Z., Li, W., Fan, Y., Zhang, Q., Zhang, F. and Fu, Y. 2015, Use of antibiotics by urban and rural residents in Heilongjiang province, China: cross-sectional study, Tropical Medicine \& International Health 20: 1815-1822.

10. Yu, M., Zhao, G., Stålsby Lundborg, C., Zhu, Y., Zhao, Q. and Xu, B. 2014, Knowledge, attitudes, and practices of parents in rural China on the use of antibiotics in children: A cross-sectional study, BioMed Central (BMC) Infectious Diseases 14: 112.

11. Andre, M., Vernby, A., Berg, J. and Lundborg, C.S. 2010, A survey of public knowledge and awareness related to antibiotic use and resistance in Sweden, Journal of Antimicrobial Chemotherapy 65: 1292-1296.

12. Hassali, M.A., Arief, M., Saleem, F., Khan, M.U., Ahmad, A., Mariam, W., Bheemavarapu, H. and Syed, I.A. 2017, Assessment of attitudes and 
practices of young Malaysian adults about antibiotics use: a cross-sectional study, Pharmacy Practice 15: 929-929.

13. Ebrahim, H.A., Ebrahim, L.A., Ebrahim, H.S. and Khaton. 2014, Knowledge, believes and practices regarding antibiotic use and misuse among rural mothers in Gharbia governorate, International Journal of Current Research 6: 7109-7116
14. Awad, A.I. and Aboud, E.A. 2015, Knowledge, attitude and practice towards antibiotic use among the public in Kuwait, PLOS ONE 10: 115.

15. Ong, S., Nakase, J., Moran, G.J., Karras, D.J., Kuehnert, M.J. and Talan, D.A. 2007, Antibiotic use for emergency department patients with upper respiratory infections: prescribing practices, patient expectations, and patient satisfaction, Annals of Emergency Medicine 50: 213-220. 